Editorial Article

\title{
Nutrition, Anaemia and Erythropoietin Therapy
}

\author{
Iain C Macdougall, BSc, MD, MRCP (UK)
}

Consultant Nephrologist and Honorary Senior Lecturer, Department of Renal Medicine, King's College Hospital, London, UK.

\section{Introduction}

During the last decade, recombinant human erythropoietin has revolutionised the management of renal anaemia. It is highly effective in the vast majority of patients treated, causing enhanced erythropoiesis and a rise in haemoglobin concentration. This has resulted not only in amelioration of uraernic symptoms, but there has also been objective evidence of improved quality-of-life, exercise capacity, and cardiac function [1]. The most striking benefits seen have been progression of left ventricular hypertrophy which is known to account for much of the high cardiovascular morbidity and mortality seen in dialysis patients, and thus the arguments for correcting renal anaemia is now overwhelming. There is also an improvement in nutrition following erythropoietin therapy, over and above the improvement in appetite associated with correction of the anaemia.

Although erythropoietin is pivotal in stimulating erythropoiesis in patients with renal failure, it is recognised that a number of other factors are involved in this process. These include other growth factors and cytokines such as stem cell factor (SCF), interleukin-3 (IL-3), interleukin-10 (IL-10), and insulin-like growth factor-1 (IGF-1), as well as a large number of nutritional "ingredients" such as iron, folic acid, vitamin B 12, vitamin B6 (pyridoxine), ascorbic acid, thyroxine, and several trace minerals.

Poor nutrition may therefore lead to a deficiency of one or more of these factors, causing in turn a suboptimal response to erythropoietin therapy. Therc has also been much discussion over the last few years as to whether it is possible to augment the response to erythropoietin with other adjuvant therapies.

Correspondence and offprim requests io: Dr. lain C Macdougall, Consultant Nephrologist, Renal Unit. King's College Hospital, East Dulwich, Grove, London SE22 8PT, UK.
The first adjuvant therapy 10 be recognised as being ablc to enhance the responsc to erythropoietin was intravenous iron |2,3|. Initially this was used when patients developed either absolute or functional iron deficiency, but it was subsequently found that IV iron had benefits even in iron- replete patients |4,5]. Other adjuvant therapics have since becn cxamined (table 1), and the aim of this article is to revicw the cvidence and potential role for these agents in the contcxt of erythropoictin therapy.

Table 1. Metabolic adjuvants to epoctin therapy.

$$
\begin{aligned}
& \text { IV iron } \\
& \text { Folic acid } \\
& \text { Vitamin B12 } \\
& \text { Vitamin B6 } \\
& \text { Ascorbic acid } \\
& \text { Vitamin D } \\
& \text { L-carnitine } \\
& \text { Androgens } \\
& |\mathrm{GF}-| / \mid \mathrm{L}-3
\end{aligned}
$$

In considering adjuvant treatment, it is important 10 distinguish between replacing a deficient substance and administcring a surfeit of a given substance. Thus, it would appear that administration of intravenous iron has positive effects in both iron deficiency and in ironrepletc states, whereas vitamin B 12 supplementation will only have a positive effect if this vitamin is deficient. In other adjuvant, therapies such as carnitine, it is not cleat whether the positive effects are secn in carnitine-deficient patients, carnitine-repletc patients, or both.

\section{IV iron}

Ever since the earliest clinical studies of erythropoictin therapy, it was obscrved that certain paticnts showing a poor response to treatment could have this reversed with IV iron administration $[2,3]$. Indeed, over the last decade it has become apparent that oral iron is largely 
ineffective in this contcxt. In both absolute iron deficiency (when total body iron stores are exhausted) and functional iron deficiency (when total body iron stores are adequate but there is a failure to release the iron rapidly enough), IV iron has proved superior to oral iron, and there are various reasons for this including poor absorption, poor bioavailability, poor compliance, and the excessive demands for iron by the bone marrow during active erythropoiesis. Intravenous administration of iron, however, results in a readily available supply of iron, which can be utilised almost immediately by the marrow [6].

More recently, it has become apparent that intravenous iron can enhance the response to erythropoietin even in iron-replete patients. Several studies have shown an augmented haemoglobin response and, perhaps more importantly, significant reductions in the dosage requirements of erythropoietin (table 2) $[4,5,7,8,9,10$, $11,12]$.

Table 2. Studics of aggressive IV iron supplementation in paticnts receiving epoetin.

\begin{tabular}{|c|c|c|c|}
\hline Reference & No of patients & Iron preparation & \% reduction in EPO dose \\
\hline Schacler and Schaefor (1992) ${ }^{7}$ & 14 & Gluconate & $47 \%$ \\
\hline Nyvad ct al $(1994)^{x}$ & 34 & Sucrose & $27 \%$ \\
\hline AI-Momen cl al (1994) & 109 & Sucrose & - \\
\hline Sunder-Plassmann \& Hbrl (1995) & 64 & Sucrose & $70 \%$ \\
\hline $\begin{array}{l}\text { Fishbane el al }(1995)^{5} \\
\text { Fis }\end{array}$ & 52 & Dextran & $46 \%$ \\
\hline Macdougall et al $(1996)^{4}$ & 37 & Dextran & $19 \%$ \\
\hline Silverberget al $(1996)^{10}$ & 41 & Sucrose & $61 \%$ \\
\hline Scpandj et al $(1996)^{\prime \prime}$ & 50 & Dextran & $35 \%$ \\
\hline Taylor et al $(1996)^{12}$ & 46 & Gluconate & $33 \%$ \\
\hline Ahsan el all (1996) & 7 & Dexiran & 26 \\
\hline
\end{tabular}

Table 3. Role of adjuvant treattment in paticnts receiving epoetin.

\begin{tabular}{|c|c|c|c|}
\hline & Deficiency & Replete & References \\
\hline $\begin{array}{l}\text { IV iron } \\
\text { Folic acid } \\
\text { Vitamin B } 12 \\
\text { Vitamin B6 } \\
\text { Ascorbic acid } \\
\text { Vitamin D } \\
\text { L- carnitine } \\
\text { Androgens } \\
\text { IGF- I/ II-.-3 }\end{array}$ & $\begin{array}{c}\vdots \\
\vdots \\
i \\
\vdots \\
i \\
i \\
x\end{array}$ & $\begin{array}{l}1 \\
x \\
x \\
y \\
y \\
x \\
i \\
i\end{array}$ & $\begin{array}{l}\text { Numerous } \\
\text { Pronai et al }(1995)^{15} \\
\text { Zachee et al }(1992)^{16} \\
\text { Mydlik et al }(1997)^{17} \\
\text { Tarng et al }(1998)^{20} \\
\text { Albitar et al }(1997)^{24} \\
\text { Labonia et al }(1995)^{28} \\
\text { Ballal el al }(1991)^{3 / 4} \\
\text { Brox ct al }(1996)^{35} \text {. Macdougall el al }(1995)^{13}\end{array}$ \\
\hline
\end{tabular}

Two of these are randomised prospective controlled studies, one in the correction phase of erythropoietin therapy, and the other in the maintenance phase.

In the study by Macdougall et al |4|, 37 paltients were randomised 10 receive either intravenous iron dextran (250mg every two wecks), oral ferrous sulphate $200 \mathrm{mg}$ tds, or no iron supplementation. All patients had to have a scrum ferritin greater than $100 \mathrm{p} . \mathrm{g} / 1$ to be entered into this study. The paticnts in the IV iron group had the best hacmoglobin response (Fig. 1), maintained their serum ferritin at bascline levels, and had the lowest erythropoictin dose requirements. In a similar study by Fishbane ct al 15/, patients in the maintenance phase of erythropoictin therapy werc randomised to IV iron dextran (100mg every two wecks) or oral iron (ferrous sulphate or iron polymaltose).

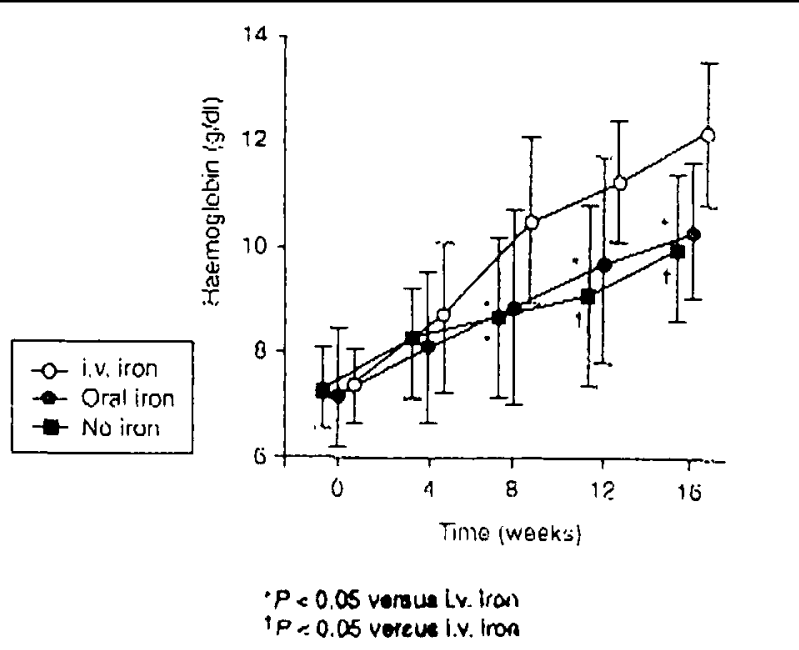

Fig. 1. Haemoglobin response $10 \mathrm{i} . \mathrm{v}$. iron (iron dextran $250 \mathrm{mg}$ every Iwo weeks), oral iron (ferrous sulphate $200 \mathrm{mg} \mathrm{l.d.s.).} \mathrm{or} \mathrm{no} \mathrm{iron} \mathrm{in} 37$ patients treated with r-1luEPO|22]. 
There was a significant increase in haematocrit in the group of patients receiving IV iron, with no change in the oral iron group (Fig. 2). The dosage requirements of epoetin fell dramatically after two months' treatment with IV iron.

Thus, the benefits of IV iron supplementation are well-established in both iron-deficient and ironreplete states.

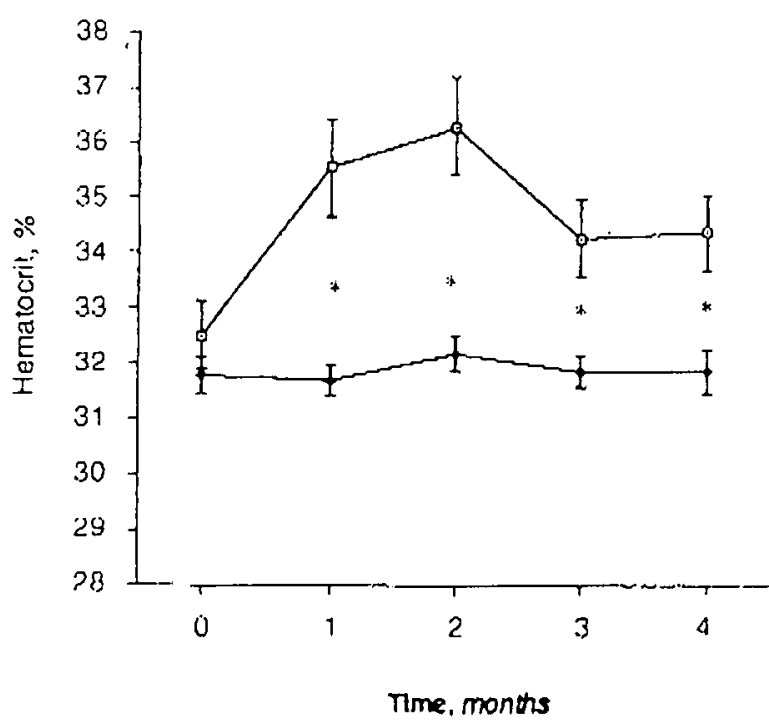

Fig. 2. Mean hematocrit in two groups of patients using epoetin. Squares indicate the intravenous iron group; diamonds indicatc the oral iron group $P<0.05$. Taken from fishbance el al [201; used with permission.

\section{Folic acid}

Folic acid is a low molecular weight substance which is water-soluble. Folate deficiency in dialysis patients is much less common than iron deficiency, but nevertheless a number of factors make such patients prone to this condition. These include losses of folate during dialysis (especially high-flux haemodialysis), poor dietary intake of folic acid due to anorexia, and occasionally the use of drugs that interfere with folate metabolism.

Some dialysis centres advocate the regular usc of folic acid supplementation in their patients, driven perhaps by the conclusions of a fairly old publication from over 30 years ago [13].

However, there is probably less dietary restriction of folate nowadays compared to the early days of dialysis, and the need for routine supplementation has been questioned [14]. It is reasonable to assume, however, that folic acid requirements will be increased in patients treated with epoetin, and hence in some patients a folate deficiency may be precipitated. Pronai et al [15] reported some resistance to epoetin in haemodialysis patients due to folate, and a clue in this study was the presence of a raised $\mathrm{MCV}$. These patients responded to folic acid supplementation at a dose of $10 \mathrm{mg}$ per day, despite having normal plasma levels of folic acid. Generally, measurements of red cell folate are preferable to serum folate in terms of sensitivity and specificity.

\section{Vitamin B12}

Vitamin $\mathrm{B} 12$ is also a small molecular weight substance which can be lost during dialysis. Nevertheless, B 12 deficiency is even less common than folate deficiency, and there is only one case report in the literature of epoetin resistance due to $\mathrm{B} 12$ deficiency which was corrected by giving B12 supplementation [16]. The authors then proceeded to screen the remainder of their dialysis population receiving epoetin, and in none of the 30 patients tested was a deficiency of $\mathrm{B} / 2$ found. Thus, although it is important to include this as a cause of epoetin resistance, particularly if there is an unexplained macrocylosis, there is no indication for routine $\mathrm{B} / 2$ supplementation in patients on epoctin.

\section{Vitamin B6}

Vitamin B6 has a role in haem synthesis and in the incorporation of iron into hacm. It is less important as al co-factor in crythropoiesis. Vitamin B6 deficiency may occur in dialysis patients as a result of poor dictary intake, impaired metabolism of the active form (pyridoxyl-5- pyrophosphate), losses in the urine (particularly when frusemide is given), and losses in the dialysate. As with iron and folate, it is likely that vitamin B6 requirements will be increased in patients recciving epoetin therapy, and this may thercfore precipitate a B6deficient state. Indecd, Mydlik et al [17] recently reported resistance to epoctin due to B6 deficiency, which was corrected by giving B6 supplementation. This may be given at a dose of $100-150 \mathrm{mg}$ per week, and it is also important to realise that a deficiency of vitamin B6 can occur in the red cells despite normal plasma levels of this vitamin [17].

\section{Ascorbic acid}

A number of dialysis paticnts are known to develop vitamin $\mathrm{C}$ deficiency, and some authors have advocated routine supplementation in this patient group $118 \mid$. Nevertheless, epoetin resistance duc to vitamin C deficiency has not been a problem, and the main interest with this vitamin is whether it could have a potential role in treating functional iron deficiency in patients with iron overload.

This was first suggested by Gastaldello et al $|19|$ who treated 4 hacmodialysis patients, all of whom were recciving epoctin and who had a functional iron deficiency despite the presence of iron overload. Administration of intravenous ascorbic acid improved the response to epoetin dramatically, and the effect was lost when the vitamin $\mathrm{C}$ was withdrawn (Fig. 3). 


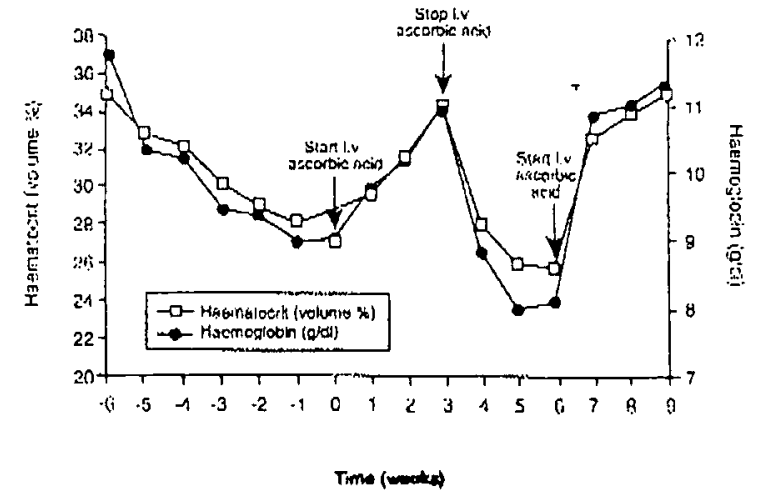

Fig. 3. Response to i.v. ascorbic acid in an iron-overloaded patient receiving r-HuEPO [27].

The response, however, was regained with further administration of vitamin $C$. these observations were put to the test in a randomised controlled prospective study from Taiwan [20]. Tarng et al recruited 50 haemodialysis patients with functional iron deficiency on epoetin despite high serum ferritin levels, and they were randomised to two protocols. each with a control group. The first protocol consisted of intravenous iron sucrose, $100 \mathrm{mg}$ across each dialysis for a total of 5 treatments. The sccond protocol involved administering intravenous ascorbic acid $100 \mathrm{mg}$ across dialysis thrice wcekly for a total of 8 wceks. The patients receiving intravenous iron showed no response, but those given intravenous ascorbic acid showed a significant rise in haematocrit and a reduction in epoelin dose requirements [20]. The serum ferritin levels in these paticnts showed a progressive fall, the transferrin saturation levels rose, and there was a decrease in the levels of zinc protoporphyrin. The suggested explanation for this effecl was mobilisation of iron from inert tissuc stores, or increased iron utilisation in the erythron. Paticnts who may be suitable for a trial of intravenous ascorbic acid would be those who are showing a poor response to epoctin therapy despite scrum ferritin levels greater than $500 \mu$ g/l. Caution, however, should be observed since it is not known what the effect of this treatment strategy is on plasma oxalate levels (which should be monitored) or oxidative stress.

\section{Vitamin D}

Il has been recognised for quite some time that sccondary hyperparathyroidism can exaccrbatc the anacmia associated with renal failure. Various explanations for this have becn offered including a direct elfect of PTH on erythroid progenitor cell growth, and the development of bone marrow fibrosis. More recently, this condition has also been found to be a causc of crythropoictin resistance [21] and again this scems to correlate with the degrce of bone marrow fibrosis. Treatment of hyperparathyroidism by either high-dose vitamin D or parathyroidectomy has been shown to improve renal anaemia even in patients not receiving epoetin $[22,23]$. Again, this has been attributed to removal of bone marrow suppression by PTH, increases in serum erythropoietin levels, and retardation of bone marrow fibrosis.

More recently, it has been found that high-dose one alfacaicidol can augment the response to epoetin, allowing reductions in dosage requirements. Two such studies have been reported within the last couple of years [24,25]. In the study by Albitar et al [24], 12 haemodialysis patients were given high-dose pulsed IV alfacalcidol, and the mean haemoglobin increased from $8.7 \pm 1.2 \mathrm{~g} / \mathrm{dl}$ at baseline to $10.3 \pm 0.98 \mathrm{~g} / \mathrm{dl}$ at 3 months Goicoechea et al [25] recently published the results of a study in 28 haemodialysis patients, 21 of whom were receiving epoetin. The patients were treated with $2 \mu \mathrm{g}$ of calcitriol intravenously after each dialysis, with subsequent dose adjustments according to PTH, calcium, and phosphate levels. After 12 months of treatment, 19 patients had shown a significant response with an increase in mean haemoglobin from $10.6 \pm 1.5 \mathrm{~g} / \mathrm{dl}$ to 12.2 $\pm 1.5 \mathrm{~g} / \mathrm{dl}(\mathrm{p}<0.001)$. The increase in haematocrit in this study correlated with the decrease in PTH leyels, and it was therefore impossible to dissociate a.direct effect of vitamin $D$ from the suppression of hyperparathyroidism [25]. It is known, however, that erythroid progenitor cells in the bone marrow do possess vitamin D receptors, and it may be that calcitriol can stimulate the proliferation and differentiation of such cells. This is certainly an interesting area of research that merits further study.

\section{L-carnitine}

Carnitine is a highly water-soluble, low molecular weight, quartenary ammonium compound which again can be lost across dialysis. It is an important carrier molecule for transporting long-chain fatty acids across the inner mitochondrial membrane, and it also appears to be important for membrane phospholipid metabolism.

Its main physiological role is felt to be in skeletal and cardiac muscle metabolism. Many of the symptoms of carnitinc deficiency are due to depletion of carnitine storcs in both cardiac and skeletal muscle, and improved cnergy and cardiac function have been reported following carnitine supplementation [26]. Ideally, carnitine deficiency should be diagnosed by a muscle biopsy, but it is possible to measure carnitine levels in the blood. In this context, both free and acyl carnitine can be measured, and carnitine deficiency is often reported to be present when the acyl carnitine (AC) to free carnitine (FC) ratio is greater than 0.4 .

A role for carnitine has also been found in stabilising the red cell membrane. Thus, it is important for red cell survival, and the life-span of the red cell population may be reduced in carnitine-deficient states. Therefore, although carnitine is not directly implicated in erythropoiesis, it seems to have a role in maintaining the natural life-span of the red cell population. 
In recent years, there has been some interest in the role of carnitine in patients receiving epoetin therapy. Kooistra et al [27] showed that the response to epoetin correlated with blood carnitine levels, with carnitine deficient patients requiring the highest doses of epoetin.

This led to the hypothesis that giving supplementary carnitine might augment the response to epoetin, and this has been the subject of several studies. The most widely quoted of these is the one by Labonia [28], in this study, patients received either L-carnitine or placebo for a period of 6 months. No change in epoetin dose requirements was seen in the placebo group, but the patients given L-carnitine had a $38 \%$ reduction in epoetin dose compared to baseline ( $p<$ 0.02) (Fig. 4).

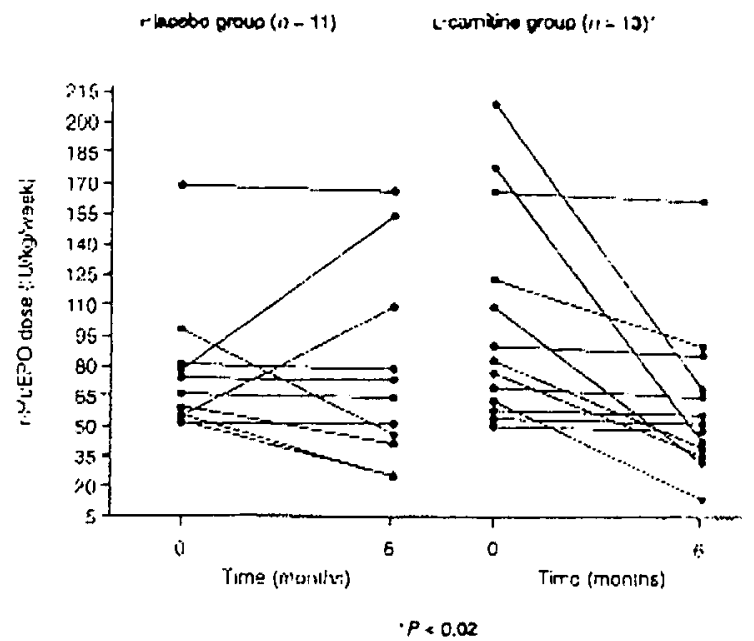

Fig. 4. Effect of 6 months of treatment with L-carnitine or placebo on $r$-HuEPO dose requirments |281.

In this study, there was no detectable change in red cell osmotic fragility or endogenous epoetin secretion. A study by Matsumura et al [29], however, confirmed a correlation between epoetin dose and free carnitine levels, in addition to showing increased red cell osmotic fragility in patients with a Iotw L-carnitine level. Administration of L-carnitine has also been found to reducc erythrocyte membrane fragility in dialysed patients $[30]$. As with vitamin D supplementation, further controlled studies of carnitine supplementation are required before the exact role of this treatment stratcgy can bc elucidated.

\section{Androgens}

It has been recognised for several decades that androgens promote crythropoiesis, and this was put to therapeutic use in the 1970 before epoctin therapy was available. Dialysis patients often showed an improvement in their anaemia with androgen supplementation, although the treatment tended to be effective in mild cases only. There are two suggested mechanisms for this effect: (1) androgens can enhance endogenous erythropoietin production; and (2) androgens may increase the sensitivity of erythroid progenitor cells to erythropoietin [31].

With the advent of epoetin therapy in the late 1980 , several workers investigated whether androgens could potentiate the effect of epoetin in dialysis

paticnts $[31,32]$. One of the carlier studies involved treating 15 adult male hacmodialysis patients with epoetin 2000 units thrice weckly, with or without the addition of $100 \mathrm{mg}$ nandrolone decanoate intramuscularly cach week [31]. After 12 weeks of therapy, the hacmatocrit had increased slightly in the group recciving cpoetin alone $(25.3 \%$ to $27.4 \%)$, but there was a much more marked response in the group receiving combination therapy $(24.4 \%$ to $32.9 \%$; p < 0.001 vs. epoetin alone).

In a longer-term study, Gaughan et al |32| treated II male and 8 female patients on haemodialysis.

One group received epoetin alone (1500 units thrice weckly for 6 months), and the other group received the same dose of epoetin along with nandrolone decanoate $100 \mathrm{mg}$ intramuscularly each wcek. Both groups showed significant incrcases in mcan haematocrit levels compared with bascline, but there was a much greater increase in the androgen-treated group compared with the group recciving epoctin alone $(8.2 \%$ vs. $3.5 \%$; $\mathrm{p}=0.012$ ). Not all studies, however, have shown a positive effect of androgen supplementation. In a controlled study by Berns el al $|33|$, no difference in the response 10 intravenous epoctin ( $120 \mathrm{U} / \mathrm{kglwcck}$ ) was secn with the addition of intramuscular nandrolone decanoatc $2 \mathrm{mg} / \mathrm{kg} /$ weck over a 16 -wcek period.

There are two concerns about using androgen adjuvant therapy. The first is the high incidence of side-effects, including virilisation, hirsutism, voice changes, acne, cholestasis, and hepatic damage. There is also a concern that androgens may increase the risk of prostatic carcinoma, and for this reason some authors have recommended that the use of androgens be confined to men aged over 50 years. There has, however, becn much interest in the polential role of androgens in augmenting the response to epoctin in countries with limiled financial resources. Cost-bencfit studies have not been performed, but it is possible that the combination of lowdose epoctin and androgen therapy may be cheaper than using epoetin alone.

\section{Other cytokines / growth factors}

Although erythropoietin is the major regulator of red cell production, a number of other cylokines and growth factors are known to be involved in this process. Some of these act at an early stage of red cell differentiation, such as stem cell factor and interlcukin-3, and a role for other factors such as interleukin-10 and insulin-like growth facior-1 has also becn identified. Insulin-like growth factor-l has becn known to stimulate erythropoiesis since 1982 1341. Erythroid progenitor cells possess IGF-I receptors, and it is via this 
mechanism that growth hormone can exert its effect on erythropoiesis.

Brox et al [35] have studied the use of IGF- I as an adjunct to epoetin in $5 / 6$ nephrectomised mice.

The animals were given sub-therapeutic doses of epoetin, IGF-1, or the combination of the two.

Neither epoetin or IGF-I on its own caused any significant change in haemoglobin, but the combination resulted in correction of anaemia in the majority of mice treated. Indeed, the response to combination therapy was similar to that seen with the maximal dose of epoetin in a dose-finding study [35]. These results suggest that the combination of epoetin and IGF- 1 could be beneficial in renal patients, but no human studies are as yet available.

Similarly, interleukin-3 is known to potentiate erythropoiesis, and indeed a deficiency of this cytokine has been suggested as a cause of epoetin resistance [36|. Interleukin-3 acts by increasing the number of colonies derived from BFU-E which results in an expansion of the erythroid progenitor cell pool [37]. In vitro studies in patients with renal anaemia receiving cpoetin therapy showed enhanced growth of BFU-E when IL-3 was added to the culture medium [38]. An in vivo study has also shown potentiation of IL-3 on crythropoicsis [39]. In this latter study, rabbits were rendered uraemic and anacmic by $5 / 6$ nephrectomy: onc group was then treated with epoelin alone while the other group received epoetin plus interleukin-3. The latter group showed a greater increase in haemoglobin concentration over the next 2-3 weeks [39].

\section{Conclusions}

Thus, it is clearly possible to potentiate the response to epoctin by co-administering other agents.

In some instances, this response is seen when there is a deficiency of a certain substance. In other cases, administration of an adjuvant such as IV iron, vilamin $D, L$-carnitine, or androgens can enhance the response to epoetin when given as a surfeit. The role of the various adjuvants described in this paper is summarised in lable 3 in relation 10 both deficiency and replete states. With most of these agents, with perhaps the exception of intravenous iron, further research is required 10 determine the exact role they may play in clinical practicc. As long as the cost of epoctin therapy remains fairly high, the challenge will continue as to the best way of optimising its ellect, and we can look forward to new developments in this expanding arca of rescarch.

\section{References}

1. Macdougall IC. Trealment of renal aneniia with recombunam human erylhropoictin. Curr Opin Nephrol Hypertens 1992; 1: 210-219.

2. Macdougall IC, Ilution RD, Cavill I, Coles GA, Williams JD. Poor response to treatment of renal anaemia with erythropoictin corrected by iron given intravenously. Br Med J 1989; 299: 1.57-158.
3. Van Wyck DB, Stivelman JC. Ruiz J, Kirlin LF, Katz MA. Ogden DA. Iron status in patients receiving erythropoietin for dialysis associated aneamia. Kidney $\operatorname{lnt} 1989 ; 35: 712-716$.

4. Macdougall IC, Tucker B. Thompson J. Tomson CRV, Baker LRI, Raine AGE. A randomized controlled study of iron supplementation in patients treated with erythropoietin. Kidney lnt 1996; 50: 1694-1699.

5. Fishbane S, Frei GL. Maesaka J. Reduction in recombinant human erythropoietin doses by the use of chronic intravenous iron supplementation. Am J Kidney Dis 1995; 26: 41 - 46.

6. Macdougall IC, Chandler G, Arrnstrong A, Breen C, Harch-owal J. Cavill 1. Characterisation of iron availability from 3 different IV iron preparations in dialysis patients. J Am Soc Nephrol 1997; 8: 221.

7. Schaefer RM. Schaefer L. Management of iron substitution during $\mathrm{r}$-HuEPO therapy in chronic renal failure patients. Erythropoiesis 1992; 3: 71-75.

8. Nyvad 0 , Danielsen $H$, Madsen $S$. Intravenous iron-sucrose complex to reduce epoetin demand in dialysis patients. Lancet 1994; 344: 1305-1306.

9. Sunder-Plassmann G. Hbrl WH. Importance of iron supply for erythropoietin therapy. Nephrol Dial Transplant 1995: 10: 20702076.

10. Silverberg DS. Blum M. Peer G, Kaplan E. laina A. Intravenous ferric saccharate as an iron supplement in dialysis patients. Nephron 1996: 72: 413-717.

11. Sepandj F. Jindal K, Wesi M, Hirsch D. Economic appraisal of maintenance parenteral iron administration in treatment of anaemia in chronic haemodialysis patients. Nephrol Dial Transplant 1996; 11: $319-322$.

12. Taylor JE. Peat N. Porter C. Morgan AG. Regular low-dose intravenous iron therapy improves response to erythropoietin in haemodialysis patients. Nephrol Dial Transplant 1996: 11: 10791083.

13. Hampers CL, Streiff R, Nathan DG, Snyder D. Merrill JP. Megaloblastic hematopoiesis in uremia and in patients on longterm hemodialysis. N Engl J Med 1967: 276: 551-554.

14. Ono $K$, Hisasue $Y$. Is lolate supplementation necessary in hemodialysis patients on erythropoietin therapy? Clin Nephrol 1992; 38: 290-292.

15. Pronai W. Riegler-Keil M. Silberbauer K, Stockenhuber F. Folic acid supplementation improves erythropoietin response. Nephron 1995: $71:$ 395-400.

16. Zachee P. Chew SL. Daelemans R. Lins RL. Erythropoietin resistance duc 10 vitamin $B 12$ deficiency. Case report and retrospective analysis of $B 12$ levels after crythropoietin treatment. Am J Nephrol 1992; 12: 188-191.

17. Mydlik M. Derssiova K. Zemberova E. Metabolism of vitamin B6 and its requitement in chronic renal failure. Kidncy Int 1997; 51 |suppl|: S56-59.

18. Dexcombes E, llanck AB. Fellay G. Water soluble vilamins in chronic hemodialysis patients and need for supplementation. Kidney Int 1993; 43: 1319-1328.

19. Gastaldello K. Verectstraeten A, Nzaine-Nye T, Vanherweghem JL, Tielemans C. Resistance to erythropoielin in iron-overloaded haemodialysis patient can be overcome by ascorbic acid adnministration. Nephrol Dial Transplant 1995; 10 |suppl. 6]: 44-47.

20. Tarng D-C. Huang T"P. A parallel comparative study of intravenous iron versus intravenous ascorbic acid for crythropoictin-hyporesponsive anaemia in haemodialysis patients with iron overload. Nephrol Dial Transplant 1998; 13: 2867-2872.

21 Rao DS, Shih MS, Mohini R. Effect of serum parathyroid hormonc and bonc marrow fibrosis on the response 10 erythropoietin in uremia. N Engl J Med 1993; 328: 171-175.

22. Barbour GL. Effect of parathyroidectomy on anelffia in chronic renal failure. Arch Intem Mcd 1979; 139:888-891.

23. Albitar S, Meulders Q. Soutif C, et al. High-dose 1-alfa-vitamin D improves anaemia in haemodialysed population in the absence of erythropoictin. Nephrol Dial Transplant 1994: 9: 1027.

24. Albitar $S$, Genin R, Fen-Chong M, Serveaux M-O, Schohn D. Chuct C. High-alfacalcidol improves anaemia in patients on haemodialysis. Nephrol Dial Transplant 1997; 12: $514-518$.

25. Goicoechea M, Vazquez MI, Ruiz MA. Gomez-Campdera F. Pere7-Garcia R, Valderrabano F. Intravenous calcitriol improves anemia and reduces the need for erythropoietin in hemodialysis patients. Nephron 1998; 78: 23-27. 
26. Golper TA, Ahmed S. L-carnitine administration to hemodialysis patients: has its time come ? Semin Dial 1992; 5: 94-98.

27. Kooistra MP, Struyvenberg A, van Es A. The response to recombinant erythropoietin in patients with the anemia of end stage renal disease is correlated with serum carnitine levels. Nephron 199 1; $57: 127-128$.

28. Labonia WD. L-carnitine effects on anemia in hemodialyzed patients treated with erythropoietin. Am J Kidney Dis 1995: 26: 757-764.

29. Matsumura M, Hatakeyama S, Koni I. Mabuchi H, Muramoto H. Correlation between serum carnitine levels and erythrocyte osmotic fragility in hemodialysis patients. Nephron 1996; 72 : 574-578.

30. Berard $E$, lordache A. Effect of low doses of L-carnitine on the response to recombinant human erythropoietin in hemodialyzed children: about two cases. Nephron 1992: 62: 368-369.

31. Ballal SH, Domoro DT, Polack DC, Marciulonis P, Martin KJ. Androgens potentiate the effects of erythropoietin in the treatment of anemia of end-stage renal disease. Am J Kidney Dis 199!: 17: 29-33.

32. Gaughan WJ, Liss KA. Dunn SR, Mangold AM, Buhsmer JP. Ifichael B. Burke JF.A 6-month study of low-dose recombinant human erythropoietin alone and in combination with androgens for the treatment of anemia in chronic hemodialysis patients. Am J Kidney Dis 1997; 30: 495-500.
33. Berns JS, Rudnick MR, Cohen RM. A controlled trial of recombinant human erythropoietin and nandrolone decanoate in the treatment of anemia in patients on chronic hemodialysis. Clin Nephrol 1992; 37: 264-267.

34. Kurtz A. Zapf J. Eckardı K-U, Clemons G, Froesch ER, Bauer C. Insulin-like growth factor I stimulates erythropoiesis in hypophysectomized rats. Proc Natl Acad Sci USA 1988; 85: 7825-7829.

35. Brox AG. Zhang F, Guyda H, Gagnon RF. Subtherapeutic crythropoietin and insulin- growth factor- I correct the anemia of chronic renal failure in the mouse. Kidney Int 1996; 50: 937-943.

36. Carozzi S. Nasini MG. Santoni 0, Tirotta A, Sanna H. Recombinant erythropoietin resistance in hemodialysis. Effects of paired filtration dialysis. ASAIO J 1997: 43: M535-538.

37. Westwood NB, Chung R, Emmerson AB, Pearson TC. The in vitro effects of stem factor, interleukin-3 and granulocytc-macrophage colony stimulating facior on hacmopoietic progenitor celis from premature infants. Br J Haematol 1994; 86: 468-474

38. Gobel V, Hoffmann HG. Muller-Wiefel DE, Braun A, Ludwig R. Scharer K. Debatin KM. Circulating haematopoietic progenilor during treatment of renal anaemia with recombinant human erythropoietin. Eur J Pediatr 1994: 153: 43-48.

39. Macdougall IC, Allen DA, Cavill I. Baker LRI, Raine AEG Intcrleukin-3 potentiates the effect of erythropoietin in a uraemic anaemic animal model. Nephrol Dial Transplant 1994; 9: 1032. 